DOI: 10.29166/odontologia.vol21.n2.2019-86-113

URL: http://revistadigital.uce.edu.ec/index.php/odontologia/article/view/2063

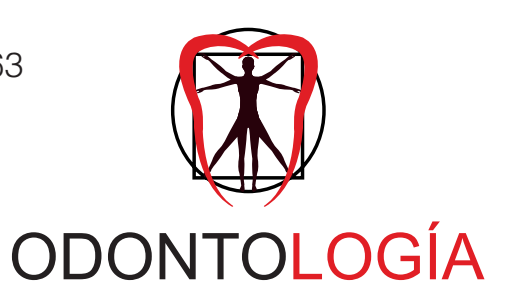

REVISIÓN BIBLIOGRÁFIGA

\title{
Cerámicas: una actualización
}

Ceramics: an update

Cerâmica: uma atualização

Marcelo Cascante Calderón ${ }^{1,2}$, Inés Villacís Altamirano,,2, Igor Studart Medeiros ${ }^{3}$

RECIBIDO: 18/12/2018 ACEPTADO: 29/03/2019 PUBLICADO: 01/07/2019

1. Postgraduate PhD Program of Biomaterials and Oral Biology, School of Dentistry, University of São Paulo (USP), São Paulo, SP, Brazil.

2. Facultad de Odontología, Universidad Central del Ecuador, Quito, Ecuador.

3. Department of Biomaterials and Oral Biology, School of Dentistry, University of São Paulo (USP), São Paulo, SP, Brazil.

\section{CORRESPONDENCIA}

Marcelo Cascante Calderón Facultad de Odontología.

Universidad Central del Ecuador.

mcascante@uce.edu.ec 


\title{
RESUMEN
}

Las cerámicas dentales utilizadas para restaurar y reemplazar tejido dental perdido de los dientes o las piezas dentales mismas, han sufrido una enorme transformación desde que aparecieron las primeras porcelanas hace ya varias décadas. Con las feldespáticas se podían hacer dientes, coronas y puentes, pero necesitaban un soporte de metal para que no sufran fracturas con los esfuerzos masticatorios, y por ello no tenían una apariencia vital. Hoy en día, han aparecido muchas otras cerámicas con diferentes y mejoradas características mecánicas y ópticas, lo que ha permitido que los odontólogos puedan por primera vez ofrecer a sus pacientes dientes artificiales con sorprendente naturalidad. Objetivo: Describir la clasificación actual, las características mecánicas y ópticas, así como la microestructura y los usos clínicos de las diferentes cerámicas dentales utilizadas hoy en día. Materiales y métodos: Revisión de la literatura acerca del tema, en tres de los más importantes buscadores de internet (Pubmed, Cochrane, Web of Science). Limitando su busqueda a artículos en inglés y publicados en los journals de investigación de materiales dentales con calificación Q1 y Q2. Resultados: Se revisaron 69 artículos publicados entre 1975 y 2019 los cuales aportaron una fuente interesante de información que permitió desarrollar el conocimiento acerca de la clasificación, microestructura, propiedades mecánicas y ópticas, usos clínicos y forma de procesamiento de las cerámicas. Conclusiones: Actualmente los odontólogos tienen a disposición una amplia variedad de materiales cerámicos con diferentes composiciones y características únicas que son necesarias conocer al momento de escoger la cerámica específica para cada necesidad de los pacientes.

Palabras clave: Porcelana dental; cerámica; restauraciones de cerámica; silicatos de aluminio; circonio; vita enamic.

\begin{abstract}
The dental ceramics used to restore and replace lost tooth tissue or the teeth have undergone a huge transformation since the first porcelains appeared several decades ago. With the feldspathic teeth, crowns and bridges could be made but, they needed a metal support so that they did not suffer fractures with the masticatory efforts, and therefore they did not have a vital appearance. Today, many other ceramics with different and improved mechanical and optical characteristics have appeared, which has allowed dentists to offer artificial teeth to their patients for the first time with surprising naturalness. Objective: Describe the current classification, mechanical and optical characteristics, as well as the microstructure and clinical uses of the different dental ceramics used today. Materials and methods: Review about the literature on the subject, in three of the most important internet search engines (Pubmed, Cochrane, Web of Science). Limiting your search to articles in English and published in the journals of research of dental materials with qualification Q1 and Q2. Results: 69 articles published between 1975 and 2019 were reviewed, which provided an interesting source of information that allowed the development of knowledge about classification, microstructure, mechanical and optical properties, clinical uses and method of processing ceramics. Conclusions: Currently, dentists have available a wide variety of ceramic materials with different compositions and unique characteristics that are necessary to know when choosing the specific ceramic for each patient need.
\end{abstract}

Keywords: Dental porcelain; ceramics; ceramic restorations; aluminum silicates; zirconium; vita enamic.

\section{RESUMO}

A cerâmica dentária usada para restaurar e substituir o tecido dentário perdido ou as próprias peças dentárias sofreram uma enorme transformação desde que as primeiras porcelanas surgiram várias décadas atrás. Com os materiais feldespáticos, podiam ser feitas coroas e pontes, mas eles precisavam de um suporte de metal para não sofrer fraturas com os esforços mastigatórios e, portanto, não tinham uma aparência de vitalidade. Hoje, outras cerâmicas com características mecânicas e ópticas diferentes e aprimoradas surgiram, o que permitiu aos dentistas oferecer dentes artificiais a seus pacientes pela primeira vez com uma naturalidade surpreendente. Objetivo: Descrever a classificação atual, características mecânicas e ópticas, bem como a microestrutura e os usos clínicos das diferentes cerâmicas odontológicas utilizadas atualmente. Materiais e métodos: Revisão da literatura sobre o assunto, em três dos mais importantes mecanismos de busca na Internet (Pubmed, Cochrane, Web of Science). Limitando a sua pesquisa a artigos em inglês e publicados nas revistas científicas de materiais dentários com qualificação Q1 e Q2. Resultados: Foram revisados 69 artigos publicados entre 1975 e 2019, que forneceram uma fonte interessante de informações que permitiram desenvolver conhecimento sobre a classificação, microestrutura, propriedades mecânicas e ópticas, usos clínicos e forma de processamento da cerâmica. Conclusões: Atualmente, os dentistas têm disponível uma ampla variedade de materiais cerâmicos com composição diferente e características únicas que são necessárias conhecer ao escolher a cerâmica específica para cada necessidade do paciente.

Palavras-chave: Restaurações cerâmicas; silicatos de alumínio; zircônio; vita enamic. 


\section{Introducción}

Desde la exitosa introducción de la primera cerámica feldespática con respaldo metálico para uso dental desarrollada por Weistein en $1960^{1}$ las cerámicas han experimentado una gran evolución con el objetivo de recuperar y reponer las estructuras dentales perdidas, como el esmalte y la dentina, por diversas causas.

En los EEUU a principios de los años 90 alrededor de 35 millones de personas usaban coronas dentales de porcelana1. En el Ecuador no disponemos de datos epidemiológicos pero se calcula que miles de personas deben tener por lo menos una corona dental y con seguridad ese número irá en aumento.

Este artículo pretende describir de manera breve y concisa la clasificación actual, las características mecánicas y ópticas, así como la microestructura y los usos clínicos de las diferentes cerámicas dentales utilizadas hoy en día.

El término cerámica proviene del griego keramiké que significa "arcilla quemada".

Las cerámicas son definidas como materiales formados por la unión de elementos metálicos como: Al, Li, Ca, Mg, K, Ti, Zr, y no metálicos como $\mathrm{O}, \mathrm{B}, \mathrm{F}^{2-3}$.

Las cerámicas dentales se componen básicamente de óxidos metálicos que, combinados o solos, se sinterizan a altas temperaturas para obtener una pieza sólida, con un reducido número de poros y resistente mecánicamente. Dependiendo de los tipos y proporciones de óxidos metálicos la microestructura obtenida después de la sinterización puede ser totalmente cristalina, vitro-cerámica o predominantemente vítrea.

Esta microestructura proporciona las propiedades ópticas (fluorescencia, translucidez/opacidad y opalescencia) y las propiedades mecánicas (resistencia al desgaste, dureza, resistencia a la flexión) ${ }^{4}$.

\section{Introduction}

Since the successful introduction of the first feldspathic ceramic with metal backing for dental use developed by Weistein in $1960^{1}$ ceramics have undergone a great evolution with the aim of recovering and replacing lost dental structures, such as enamel and dentin, by various causes.

In the US in the early 90 about 35 million people used porcelain dental crowns ${ }^{1}$. In Ecuador we do not have epidemiological data but it is estimated that thousands of people must have at least one dental crown and that number will surely increase.

This article aims to briefly and concisely describe the current classification, mechanical and optical characteristics, as well as the microstructure and clinical uses of the different dental ceramics used today.

The term ceramic comes from the Greek keramiké which means "burnt clay".

Ceramics are defined as materials formed by the union of metallic elements such as: $\mathrm{Al}, \mathrm{Li}, \mathrm{Ca}, \mathrm{Mg}, \mathrm{K}, \mathrm{Ti}, \mathrm{Zr}$, and nonmetals such as $\mathrm{O}, \mathrm{B}, \mathrm{F}^{2,3}$.

Dental ceramics are basically composed of metal oxides that, combined or alone, are sintered at high temperatures to obtain a solid piece, with a reduced number of pores and mechanically resistant. Depending on the types and proportions of metal oxides, the microstructure obtained after sintering can be totally crystalline, vitro-ceramic or predominantly vitreous.

This microstructure provides the optical properties (fluorescence, translucency / opacity and opalescence) and mechanical properties (wear resistance, hardness, flexural strength $)^{4}$. 
Debido al tipo de enlace y su microestructura, este material es inerte químicamente y por tanto biocompatible; posee altos valores de resistencia a la compresión, dureza, y fundamentalmente cuando es tratado con colores y pigmentos puede asemejar la apariencia natural del diente, es muy apreciado por los dentistas, técnicos y pacientes para rehabilitar los tejidos dentales perdidos 5 .

Sin embargo ellas son frágiles y no son capaces de deformarse plásticamente, tienen un alto módulo de elasticidad y con tan solo una deformación de 0,01\% pueden experimentar fracturas catastróficas.

Otra de las desventajas de las cerámicas es que debido a sus altos valores de dureza son capaces de producir desgaste de los dientes antagonistas, especialmente cuando no están bien pulidas o glaseadas².

\section{Clasificación actual}

Las cerámicas actualmente son clasificadas de acuerdo a su composición microestructural y a su capacidad de reaccionar frente al ataque ácido en:

- Cerámicas vítreas compuestas principalmente por sílica (feldespática): ácido sensibles

- Cerámicas vítreas compuestas por sílica pero con cristales de relleno (leucítica y disilicato de lítio, silicato de litio): ácido sensibles

- Cerámicas policristalinas (zirconia): ácido resistentes ${ }^{3,6}$.

\section{Ceramicas feldespaticas o porcela- nas dentales}

Las cerámicas feldespáticas provienen de un mineral rocoso llamado feldespato, que es muy abundante en la naturaleza y cuya composición principal es sílica, y otros minerales como el cuarzo, el caolín y la arcilla.

Para poder utilizar el feldespato $\left(\mathrm{Na}_{2} \mathrm{O} / \mathrm{K}_{2} \mathrm{O}\right.$. $\mathrm{Al}_{2} \mathrm{O}_{3} \cdot 6 \mathrm{SiO}_{2}$ ) como materia prima en la fabricación de la porcelana es preciso eli-
Due to the type of bond and its microstructure, this material is chemically inert and therefore biocompatible; It has high values of compressive strength, hardness, and fundamentally when treated with colors and pigments it can resemble the natural appearance of the tooth, it is highly appreciated by dentists, technicians and patients to rehabilitate lost dental tissues ${ }^{5}$.

However, they are fragile and are not able to deform plastically, have a high modulus of elasticity and with only a deformation of $0.01 \%$ can experience catastrophic fractures.

Another of the disadvantages of ceramics is that due to their high hardness values they are capable of causing wear of the opposing teeth, especially when they are not well polished or glazed².

\section{Current classification}

Ceramics are currently classified according to their microstructural composition and their ability to react to acid attack in:

- Vitreous ceramics composed mainly of silica (feldspathic): sensitive acids

- Vitreous ceramics composed of silica but with filler crystals (leucite and lithium disilicate, lithium silicate): sensitive acids

- Polycrystalline ceramics (Zirconia): acid resistant ${ }^{3,6}$.

\section{Feldespatic ceramics or dental porcelains}

Feldspathic ceramics come from a rocky mineral called feldspar, which is very abundant in nature and whose main composition is silica, and other minerals such as quartz, kaolin and clay.

In order to use feldspar $\left(\mathrm{Na}_{2} \mathrm{O} / \mathrm{K}_{2} \mathrm{O} \cdot \mathrm{Al}_{2} \mathrm{O}_{3}\right.$. $6 \mathrm{SiO}_{2}$ ) as a raw material in the manufacture of porcelain it is necessary to remo- 
minar el hierro como contaminante de su composición a través de ciertos procesos químicos, mezclarlo con cuarzo y someterlo a altas temperaturas $\left(1300^{\circ} \mathrm{C}\right)$. A esta temperatura se produce un fenómeno único conocido como "fusión incongruente" en el cual se forma la fase vítrea, y dentro de ella empiezan a crecer los cristales de leucita, pero de manera dispersa en su interior ${ }^{2}$.

Los fabricantes entonces someten esta masa a un enfriamiento brusco de ella lo que produce una fractura en varios pedazos que se llaman "frita". Estos pedazos de frita son sometidos a un proceso de molienda en grandes molinos de bolas de zirconio, durante varias semanas hasta obtener un polvo fino y delicado al cual se le agregaran pigmentos de óxidos metálicos para proporcionarle los colores semejantes al diente natural.

Este polvo final será mezclado con un líquido, por parte del protésico para realizar el modelado de la pieza dental².

Debido a que la fase vítrea está presente en alrededor del 75 al $85 \%$ del volumen total de esta porcelana y los cristales representan apenas del 15 al 25\% del total a estas se las llama cerámicas de matriz vítrea o simplemente vítreas ${ }^{3,6,7}$.

En tanto, debido al hecho de que el ácido fluorhídrico (HF) es capaz de disolver la matriz vítrea y dejar expuestos los cristales de la fase cristalina-9 lo que produce una superficie irregular muy adecuada para mejorar la humectabilidad de un agente de enla$c e^{8,10}$, a esta porcelana se la llama también ácido-débil.

\section{Propiedades mecánicas y ópticas}

En general las porcelanas dentales al igual que las demás cerámicas a diferencia de los metales presentan una escasa habilidad para absorber grandes cantidades de energía antes de sufrir una fractura catastrófica.

Las feldespáticas son las más débiles (menos resistentes) de todas debido a que ve iron as a pollutant from its composition through certain chemical processes, mix it with quartz and submit it to high temperatures $\left(1300^{\circ} \mathrm{C}\right)$. At this temperature there is a unique phenomenon known as "incongruous fusion" in which the vitreous phase is formed, and inside it the leucite crystals begin to grow, but in a scattered way inside?

The manufacturers then submit this dough to an abrupt cooling of it which produces a fracture in several pieces called "frita". These pieces of frit are subjected to a grinding process in large mills of zirconium balls, for several weeks until obtaining a fine and delicate powder to which metal oxide pigments will be added to provide the colors similar to the natural tooth.

This final powder will be mixed with a liquid, by the prosthetic to perform the modeling of the dental piece? ${ }^{2}$.

Due to the vitreous phase is present in about 75 to $85 \%$ of the total volume of this porcelain and the crystals represent only 15 to $25 \%$ of the total, these are called vitreous or simply vitreous ceramic ceramics $^{3,6,7}$.

Meanwhile, due to the fact that hydrofluoric acid (HF) is capable of dissolving the vitreous matrix and exposing crystals of the crystalline phase ${ }^{8,9}$, which produces a very suitable irregular surface to improve the wettability of an agent. bonding ${ }^{8,10}$, this porcelain is also called acid-weak.

\section{Mechanical and optical properties}

In general, dental porcelains, like other ceramics, unlike metals, have a poor ability to absorb large amounts of energy before suffering a catastrophic fracture.

The feldspathic are the weakest (least resistant) of all because they have a large 
poseen un gran porcentaje de fase vítrea en su interior y muy poco de fase cristalina. La tenacidad a la fractura $\left(K_{\mathrm{IC}}\right)$ y la baja resistencia a la tracción se encuentran en relación directa a este fenómeno. Es decir a menor contenido de leucita, menor $\mathrm{K}_{\mathrm{IC}} \mathrm{y}$ viceversa. César et al, reportan valores bajos entre 0,71 y 0,75 $\mathrm{K}_{\mathrm{IC}}$ en porcelanas con $0 \%$ de contenido de leucita, mientras que presentan valores más altos de entre 1,22 y $1,23 \% K_{I C}$ en porcelanas con un 22 y $23 \%$ de leucita ${ }^{11}$. Otros trabajos de investigación muestran valores similares de $\mathrm{K}_{\mathrm{IC}}{ }^{12-16}$.

Esto se debe al hecho de que en una matriz vítrea la presencia de defectos, fallas intrínsecas, o microcraks producidos durante la fase del enfriamiento brusco cuando son procesadas, o incluidos al momento de fabricar las piezas dentales, al ser sometidos a fuerzas o stress masticatorio se van propagando sin ningún obstáculo en su camino hasta producir la rotura del material.

En tanto que en una porcelana reforzada con fase cristalina, la presencia de los cristales de leucita se oponen al avance de un defecto, o incluso lo comprimen, deteniendo su paso y mejorando su resistencia mecánica a la fractura ${ }^{12}$.

Por esta razón las porcelanas feldespáticas necesitan una estructura interna de un material con una alta $\mathrm{K}_{\mathrm{IC}}$ como la propia estructura dentaria remanescente, los metales $u$ otro tipo de cerámicas, para poder sobrevivir en la boca sin riesgo de sufrir daños o roturas.

En cuanto a sus propiedades ópticas, las feldespáticas con gran volumen de matriz vítrea, dejan pasar la luz y consecuentemente son translucidas, pero mientras mayor sea el contenido de cristales de leucita, la luz irá a chocar con ellos y se desviará con lo cual será más opaca.

Es bien sabido que el incremento de ciertos óxidos y polvos colorantes permiten hacer restauraciones dentales de gran similitud al color del diente, e incluso de la encía. percentage of vitreous phase inside and very little crystalline phase. Fracture toughness $\left(\mathrm{K}_{\mathrm{IC}}\right)$ and low tensile strength are directly related to this phenomenon. In other words, the lower the leucite content, the lower $\mathrm{K}_{\mathrm{IC}}$ and vice versa. César. et al, report low values between 0.71 and 0.75 $\mathrm{K}_{\mathrm{IC}}$ in porcelains with $0 \%$ leucite content, while having higher values of between 1.22 and $1.23 \% \mathrm{~K}_{\mathrm{IC}}$ in porcelains with 22 and $23 \%$ of leucite ${ }^{11}$. Other research papers show similar values of $\mathrm{K}_{\mathrm{IC}}{ }^{12-16}$.

This is due to the fact that in a vitreous matrix the presence of defects, intrinsic failures, or microcraks produced during the phase of abrupt cooling when they are processed, or included at the time of manufacturing the dental pieces, when subjected to forces or masticatory stress they spread without any obstacle in their path until the material breaks.

While in a porcelain reinforced with crystalline phase, the presence of leucite crystals opposes the progress of a defect, or even compresses it, stopping its passage and improving its mechanical resistance to fracture ${ }^{12}$.

For this reason feldspathic porcelains need an internal structure of a material with a high $\mathrm{K}_{\mathrm{IC}}$ such as the remanescent dental structure itself, metals or other ceramics, in order to survive in the mouth without risk of damage or breakage.

As for their optical properties, feldspaths with a large volume of vitreous matrix, let the light in and consequently are translucent, but the higher the content of leucite crystals, the light will collide with them and deviate with what will be more opaque.

It is well known that the increase of certain oxides and dusts allows dental restorations of great similarity to the color of the tooth, and even the gum. 
Las porcelanas feldespáticas están compuestas por dos fases: una fase o matriz vítrea y una fase cristalina, conformada por cristales de leucita. Dichos cristales pueden tener un largo de entre 5 a $10 \mu \mathrm{m}$ y son muy similares a las prolongaciones de una dendrita $^{16}$.

Catell et al,encontraron una alta proporción (7-10\%) de defectos esféricos o microporos dentro de la fase vítrea y en las vecindades de los cristales de leucita, que parecería que actúan como detonadores de stress cuando están sometidos a fuerzas que causan un tensión interna. Esto explicaría su baja resistencia a la fractura y a la tracción ${ }^{13}$.

Dichos poros se formarían al momento del enfriamiento brusco de la masa de frita cuando se fabrica el polvo de la porcelana.

\section{Usos clínicos}

Coronas y puentes de hasta 3 unidades de metal-porcelana, para lo cual los fabricantes de polvos de porcelana ajustan el coeficiente de expansión térmica linear (CETL) de la cerámica al del metal mediante la adición de leucita, con el objeto de evitar que una gran diferencia en el CETL produzca zonas de concentración de stress y por lo tanto fracturas del material, durante el enfriamiento.

Mientras que el técnico dental somete la infraestructura de la aleación metálica a un tratamiento previo de oxidación del metal para que se produzca una unión química entre ambos ${ }^{2}$.

Inlays, onlays de porcelana libres de metal. Aunque parezca una contradicción a todo lo que hemos venido tratando hasta ahora, el desarrollo de técnicas y adhesivos modernos ha permitido que la adhesión entre las porcelanas y el esmalte sea muy confiable y óptima en orden de resistir las fuerzas de la masticación ${ }^{17}$.

Facetas o carillas de porcelana pura. Ensayos clínicos demuestran que las tasas de supervivencia de estas restauraciones se
Feldspathic porcelains are composed of two phases: a vitreous phase or matrix and a crystalline phase, made up of leucite crystals. Said crystals can have a length of between 5 to $10 \mu \mathrm{m}$ and are very similar to the extensions of a dendrite ${ }^{16}$.

Catell et, al found a high proportion (7$10 \%)$ of spherical or micropore defects within the vitreous phase and in the vicinity of the leucite crystals, which would appear to act as stress detonators when subjected to stress-causing forces. internal This would explain its low fracture and tensile strength ${ }^{13}$.

Such pores would form at the time of the sudden cooling of the frit mass when the porcelain powder is manufactured.

\section{Clinical uses}

Crowns and bridges of up to 3 metal-porcelain units, for which the manufacturers of porcelain powders adjust the linear thermal expansion coefficient (LTEC) of the ceramic to the metal by adding leucite, in order to prevent a great difference in the LTEC produces areas of stress concentration and therefore fractures of the material, during cooling.

While the dental technician submits the metal alloy infrastructure to a pretreatment of metal oxidation so that a chemical bond between them occurs ${ }^{2}$.

Inlays, metal-free porcelain onlays. Although it seems a contradiction to everything we have been trying until now, the development of modern techniques and adhesives has allowed the adhesion between porcelains and enamel to be very reliable and optimal in order to resist the forces of chewing $^{17}$.

Facets or veneers of pure porcelain. Clinical trials show that the survival rates of these restorations are between 82 and 
encuentran entre el 82 al 96\% después de 10 a 21 años ${ }^{17,18}$ siempre y cuando hayan sido preparadas y cementadas en esmalte exclusivamente ${ }^{19}$ cuando la preparación y el tallado haya expuesto un $50 \%$ o más dentina se encontraron más fallas por despegamiento y fractura. Como lo reportó Beier et al., en 2012.

\section{Procesamiento}

Las restauraciones dentales a base de porcelana feldespática se pueden obtener por medio de sinterización, inyección y CAD CAM.
$96 \%$ after 10 to 21 years ${ }^{17,18}$ as long as they have been prepared and cemented in enamel exclusively ${ }^{19}$ when the preparation and carved exposed $50 \%$ or more dentin were found more failure due to detachment and fracture. As reported by Beier et al., in 2012.

\section{Processing}

Dental restorations based on feldspathic porcelain can be obtained by sintering, injection and CAD CAM.

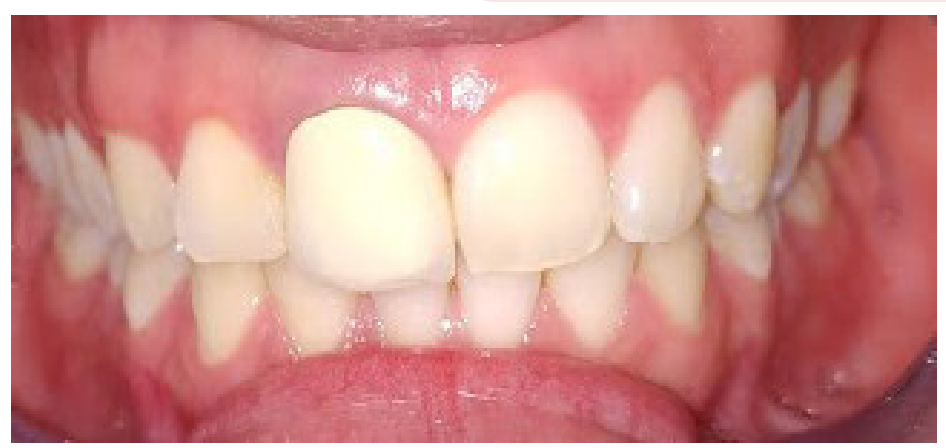

Figura 1. Corona dental en metal cerámica; Dental crown in ceramic metal.

Nota: Nótese la opacidad del respaldo metálico en cervical, debido a la gran translucidez de la cerámica feldespática; Note the opacity of the cervical metal backing, due to the great translucency of feldspathic ceramics.

\section{Leucita}

Una de las principales cerámicas a base de leucita fue presentada en 1991 bajo el nombre de IPS Empress Ceramic. (Ivoclar Vivadent, Leichtenstein). Pertenece al grupo de las cerámicas vítreas y por tanto son también ácidos débiles, pero a diferencia de la anterior, esta posee un alto porcentaje de fase cristalina en forma de cristales de leucita. Estos cristales son añadidos por el fabricante por medio de la adición de un polvo de feldespato sintético $\left(\mathrm{K}_{2} \mathrm{O}, \mathrm{Al}_{2} \mathrm{O}_{3}\right.$,$\left.6 \mathrm{SiO}_{2}\right)^{20}$. Y además los fabricantes son capaces de controlar la cantidad y la calidad de los cristales por medio de diversos tratamientos.

La proporción de los cristales de leucita en la fase cristalina puede variar desde el 22 al $50 \%$ en estas porcelanas en tanto que la

\section{Leucita}

One of the main leucite-based ceramics was presented in 1991 under the name of IPS Empress Ceramic. (Ivoclar Vivadent, Leichtenstein). It belongs to the group of vitreous ceramics and therefore they are also weak acids, but unlike the previous one, it has a high percentage of crystalline phase in the form of leucite crystals. These crystals are added by the manufacturer through the addition of a synthetic feldspar powder $\left(\mathrm{K}_{2} \mathrm{O}, \mathrm{Al}_{2} \mathrm{O}_{3}, 6 \mathrm{SiO}_{2}\right)^{20}$. And also the manufacturers are able to control the quantity and quality of the crystals by means of various treatments.

The proportion of leucite crystals in the crystalline phase can vary from 22 to $50 \%$ in these porcelains while the vitreous phase is for- 
fase vítrea está formada de un vidrio de aluminio silicato ${ }^{3}$.

Las diferencias entre estos porcentajes del contenido de leucita puede estar inducida por diversos factores que incluyen: múltiples cocciones de la porcelana ${ }^{21}$, tratamientos térmicos ${ }^{22}$, enfriamientos, e inclusive las largas exposiciones a la saliva hacen que la porcelana madure y contenga mayor porcentaje de leucita ${ }^{23}$.

Trabajos de investigación demuestran que un porcentaje de leucita entre el 20 al 30\% es capaz de mejorar las propiedades mecánicas de esta porcelana ${ }^{24,25}$, mientras que a mayor porcentaje, entre el 30 y 50\%, dichas propiedades no aumentan significativamente ${ }^{11}$.

\section{Propiedades mecánicas y ópticas}

Las propiedades mecánicas de la leucita al igual que la feldespática, están influenciadas por las diferencias entre los coeficientes de expansión térmica de los cristales de leucita y la fase cristalina, durante el enfriamiento de la misma al momento de ser producida.

Sin embargo este procedimiento puede producir microfisuras en el interior del material, debido fundamentalmente a que al existir mucha diferencia entre la expansión térmica de una fase vítrea y una cristalina, se forman tensiones entre ellas que pueden desencadenar fisuras o defectos por stress térmico lo que puede llevar a una fractura del material cuando es sometido a esfuerzo mecánico.

En efecto, Kon et al., observaron por medio del microscopio electrónico de barredura la formación de microfisuras alrededor de los extremos de las puntas de los cristales de leucita, y que estas iban agrandandándose cuando más porcentaje de leucita estaba presente 25 .

En lo que tiene que ver con su dureza (dureza Vickers $H V$ ) se han reportado valores de $450 \mathrm{HV}$ en porcelanas con un porcentaje med of a silicate aluminum glass ${ }^{3}$.

The differences between these percentages of the leucite content may be induced by various factors including: multiple porcelain firing $^{21}$, heat treatments ${ }^{22}$, cooling, and even long exposures to saliva make the porcelain mature and contain higher percentage of leucite ${ }^{23}$.

Research shows that a percentage of leucite between 20 and $30 \%$ is able to improve the mechanical properties of this porcelain ${ }^{24}$, 25 , while at a higher percentage between 30 and $50 \%$ these properties do not increase significantly ${ }^{11}$.

\section{Mechanical and optical properties}

The mechanical properties of leucite, as well as feldspathic, are influenced by the differences between the coefficients of thermal expansion of leucite crystals and the crystalline phase, during cooling of the same at the time of being produced.

However, this procedure can produce microcracks inside the material, mainly due to the fact that there is much difference between the thermal expansion of a glassy phase and a crystalline phase, tensions are formed between them that can trigger cracks or defects due to thermal stress, which can lead to a fracture of the material when subjected to mechanical stress.

In fact, Kon et al., observed, by means of the scanning electron microscope, the formation of microcracks around the ends of the tips of the leucite crystals, and that these were enlarging when a higher percentage of leucite was present ${ }^{25}$.

Regarding its hardness (Vickers HV hardness), $450 \mathrm{HV}$ values have been reported in porcelains with a leucite percentage of 20 to 
de leucita del 20 al 50\%. Mientras que otras porcelanas feldespáticas con valores más altos de leucita decrecen la misma entre 350 y $400 \mathrm{HV}^{25}$.

En lo que tiene que ver con la resistencia a la flexión, la leucita alcanza valores de 81 $\mathrm{MPa}$, a diferencia de las porcelanas feldespáticas que tienen valores mucho más bajos.

Kon et al., reportaron que cuando los porcentajes de leucita se encuentran más allá del $50 \%$ las propiedades mecánicas, empeoran.

En cuanto a sus propiedades ópticas; debido a la mejor distribución de los cristales de leucita dentro de la matiz vítrea, la translucidez, es excelente debido a que la luz puede atravesar por ella con mucha facilidad, sin embargo se ha observado que esta propiedad decrece a medida que aumenta el grosor del material26.

\section{Microestructura}

Presentan una microestructura muy similar a la descrita para las feldespáticas, es decir tienen una matriz vítrea con cristales de leucita en su interior, solo que en estas cerámicas, los cristales se encuentran más homogéneamente distribuidos en su interior, esto se debe a que la leucita es adicionada en forma de polvo al momento de producirlas, y por medio de tratamientos térmicos los fabricantes son capaces de controlar el crecimiento y la calidad de dichos cristales.

\section{Usos clínicos}

Prótesis de metal cerámica de hasta 3 unidades, coronas de metal-porcelana ${ }^{27}$ inlays, onlays, recubrimiento de infraestructuras de metal o de otras cerámicas ya sean vítreas o cristalinas, carillas y facetas tipo lentes de contacto $^{27}$. Con muy buenos resultados de durabilidad a mediano plazo (8 años) pero con serios riesgos de sufrir fracturas pasados los 10 años de uso clínico en boca ${ }^{28}$.
$50 \%$. While other feldspathic porcelains with higher leucite values decrease the same between 350 and $400 \mathrm{HV}^{25}$.

In what has to do with flexural strength, leucite reaches values of $81 \mathrm{MPa}$, unlike feldspathic porcelains that have much lower values.

Kon et al., reported that when the percentages of leucite are beyond $50 \%$ mechanical properties, they worsen.

As for its optical properties; Due to the better distribution of leucite crystals within the vitreous hue, the translucency is excellent because the light can pass through it very easily, however it has been observed that this property decreases as the thickness of the material26.

\section{Microstructure}

They have a microstructure very similar to that described for feldspathic, that is to say they have a vitreous matrix with leucite crystals inside, only that in these ceramics, the crystals are more homogeneously distributed inside, this is because the leucite It is added in powder form at the time of production, and by means of heat treatments manufacturers are able to control the growth and quality of these crystals.

\section{Clinical uses}

Ceramic metal prostheses of up to 3 units, metal-porcelain crowns $^{27}$ inlays, onlays, coating of metal or other ceramic infrastructures, either vitreous or crystalline, veneers and contact lens type facets ${ }^{27}$. With very good results of durability in the medium term (8 years) but with serious risks of suffering fractures after 10 years of clinical use in the mouth ${ }^{28}$. 


\section{Procesamiento}

Las restauraciones dentales a base de leucita se pueden obtener por medio de diversos métodos como: sinterización, inyección y CAD CAM

\section{Vitro-cerámicas (disilicato de litio, silicato de litio con zirconia)}

Un material que ha evolucionado mucho y que actualmente se destaca en la odontología es el disilicato de litio, silicato de litio con zirconia o mejor conocidos como vitro-cerámicas.

Estos materiales combinan las características ópticas favorables con la resistencia mecánica intermedia, cuando es comparada con las demás cerámicas odontológicas.

El disilicato de litio $\left(\mathrm{LS}_{2}\right.$ ) está clasificado como una cerámica vítrea pero con partículas y cristales de disilicato de litio como relleno. Por lo tanto también son consideradas ácido-débiles.

Fueron presentadas por primera vez en el mercado a principios de los años 90 con el nombre comercial de IPS EMPRESS 2 (Ivoclar Vivadent, Shaan, Liechestein) ${ }^{29}$ y estaba compuesta por $65 \%$ de agujas o cristales de disilicato de litio sumergidas en una masa de vidrio con $1 \%$ de porosidad ${ }^{30,31}$.

Actualmente, fueron substituidas por el sistema e.max Press e e.max CAD. A pesar de que el valor de su porosidad es bajo, Zarone et al., encontraron que puede ser un factor decisivo e influenciar la dureza del material, disminuir su tenacidad a la fractura hasta en un $50 \%$, sobre todo cuando no existe una perfecta adaptación entre el disilicato y el sustrato dentario; no se ha realizado una técnica correcta de cementación, o ha existido un desgaste de la pieza de cerámica después del cementado.

Los cristales de disilicato de litio pueden ser añadidos por el fabricante por medio del control preciso de la composición del vidrio, sometiendo a un tratamiento térmico

\section{Processing}

Dental restorations based on leucite can be obtained through various methods such as sintering, injection and CAD CAM.

Vitro-ceramic (lithium disilicate, lithium silicate with zirconia)

A material that has evolved a lot and currently stands out in dentistry is lithium disilicate, lithium silicate with zirconia or better known as vitro-ceramics.

These materials combine favorable optical characteristics with intermediate mechanical resistance, when compared to other dental ceramics.

Lithium disilicate $\left(\mathrm{LS}_{2}\right)$ is classified as a vitreous ceramic but with particles and lithium disilicate crystals as filler. Therefore they are also considered acid-weak.

They were presented for the first time on the market in the early 90 under the trade name of IPS EMPRESS 2 (Ivoclar Vivadent, Shaan, Liechestein $)^{29}$ and was composed of $65 \%$ needles or lithium disilicate crystals immersed in a glass mass with $1 \%$ porosity ${ }^{30}, 31$.

Currently, they were replaced by the e.max Press and e.max CAD system. Although the value of its porosity is low, Zarone et al, found that it can be a decisive factor and influence the hardness of the material, decrease its fracture toughness by up to $50 \%$, especially when there is no perfect adaptation between the disilicate and the dental substrate; a correct cementation technique has not been performed, or there has been a wear of the ceramic piece after cementation.

The lithium disilicate crystals can be added by the manufacturer by means of the precise control of the composition of the glass, subjecting a thermal treatment to the mass 
a la masa del mismo que causa la precipitación y el crecimiento de los cristales dentro de ella. Dado que ambas fases derivan del vidrio es lógico pensar que toda la masa se altera durante este proceso, al que se lo llama "ceramización"27.

\section{Propiedades mecánicas y ópticas}

Esta cerámica al igual que las anteriores tienen poca tolerancia a la deformación permanente, ellas son incapaces de deformarse plásticamente, lo que les convierte en materiales frágiles. Sin embargo En los últimos años los fabricantes han introducido mejoras en el proceso de ceramización y en el proceso de CAD CAM introduciendo bloques precristalizados (IPS e.max CAD, Ivoclar Vivadent) con un porcentaje del 40\% de metasílicato de litio $\left(\mathrm{Li}_{2} \mathrm{Si}_{2} \mathrm{O}_{5}\right)$ disponible en diferentes grados de translucidez y colores. Estos bloques son sometidos al tallado de la pieza dentro del CAD CAM para luego ser calentados a $840-850^{\circ} \mathrm{C}$ por 10 minutos lo que produce un precipitado del metasilicato que evoluciona en disilicato de lítio $(70 \%)^{32}$ el cual llega a alcanzar una resistencia a la flexión de $360 \mathrm{MPa}$ a $400 \mathrm{MPa}^{33,34}$ que es dos o tres veces más el valor de las porcelanas feldespáticas y leucíticas con lo cual se convierte en un material de mejores características que los anteriores ${ }^{35}$.

A pesar de poseer altos valores de resistencia a la fractura y a la flexión, el disilicato todavía no tolera deformaciones mayores o la presencia de irregularidades que estén sometidas a stress. Lo que significa clínicamente que una vez cementado los ajustes intraorales deben ser hechos con bastante cuidado para evitar la producción excesiva de defectos que pueden resultar en la reducción de la resistencia a la fractura de la pieza.

Además, el acabamiento y pulido son etapas esenciales para garantizar mayor duración de la pieza cementada.

En cuanto a sus propiedades ópticas, se puede afirmar que el disilicato puede ser thereof that causes the precipitation and growth of the crystals within it. Since both phases derive from glass, it is logical to think that the entire mass is altered during this process, which is called "ceramization" 27.

\section{Mechanical and optical properties}

This ceramic, like the previous ones, has little tolerance for permanent deformation, they are unable to deform plastically, which makes them fragile materials. However, in recent years, manufacturers have made improvements to the ceramization process and the CAD CAM process by introducing pre-crystallized blocks (IPS e.max CAD, Ivoclar Vivadent) with a $40 \%$ percentage of lithium metasilicate $\left(\mathrm{Li}_{2} \mathrm{Si}_{2} \mathrm{O}_{5}\right)$ available in different degrees of translucency and colors. These blocks are subjected to the carving of the piece inside the CAD CAM and then be heated at $840-850^{\circ} \mathrm{C}$ for 10 minutes which produces a precipitate of metasilicate that evolves in lithium disilicate $(70 \%)^{32}$ which reaches a Flexural strength from 360 $\mathrm{MPa}$ to $400 \mathrm{MPa}^{33,34}$ which is two or three times the value of feldspathic and Leukitic porcelains, which makes it a material with better characteristics than the previous ones $^{35}$.

Despite having high values of resistance to fracture and flexion, the disilicate still does not tolerate major deformations or the presence of irregularities that are subjected to stress. Which means clinically that once the intraoral adjustments are cemented, they must be done with enough care to avoid excessive production of defects that can result in the reduction of the fracture resistance of the piece.

In addition, finishing and polishing are essential stages to ensure longer duration of the cemented piece.

As for its optical properties, it can be affirmed that the disilicate can be more trans- 
más translucido dependiendo de la fase vítrea presente, o más opaco dependiendo del tamaño y la cantidad de cristales. Los fabricantes han sido capaces de proporcionar una gama amplia de colores y sombras que incluso se pueden combinar con tintes y óxidos metálicos para que los técnicos dentales y los odontólogos puedan asemejar el color natural de los dientes.

Una última propiedad diferente a la de las demás cerámicas es su biocompatibilidad.

En efecto se han observado reacciones favorables de los tejidos dentales blandos y duros de la boca frente al uso del disilicato. Foster et al., 2014, presentaron los resultados de una investigación en la cual observó que este material cerámico permitió el desarrollo y crecimiento de fibroblastos, debido fundamentalmente a su estructura microscópica granular que le permite tener micro espacios entre sus moléculas lo que permitiría el imbricamiento de prolongaciones celulares entre ellas ${ }^{36}$, lo cual puede corroborase en observaciones in vivo puesto que no se ha visto reacciones inflamatorias en los tejidos blandos que circundan a las coronas y restauraciones de cerámica de estos materiales en pacientes que los están usando.

Al contrario de los tejidos inflamados que se han podido apreciar en cientos de pacientes que usan coronas y puentes de metal-porcelana o de otro tipo de polímeros restauradores.

\section{Microestructura}

Presentan un $30 \%$ de fase vítrea $\left(\mathrm{SiO}_{2}, \mathrm{~K}_{2} \mathrm{O}\right.$, $\mathrm{MgO}, \mathrm{Al}_{2} \mathrm{O}_{3}, \mathrm{P}_{2} \mathrm{O}_{5}$ ) y un $70 \%$ de cristales principalmente en forma de agujas microscópicas de disilicato de litio $\left(\mathrm{Li}_{2} \mathrm{Si}_{2} \mathrm{O}_{5}\right)$ entrecruzados entre ellos ${ }^{37}$ y a su vez sumergidos dentro de la matriz vítrea.

Dichos cristales microscópicos tendrían entre 5 y $6 \mu \mathrm{m}$ de largo y 0,5 a 0,8 $\mu \mathrm{m}$ de espesor $^{38}$. La cualidad de estos cristales ha hecho que esta cerámica gane en resisten- lucent depending on the glassy phase present, or more opaque depending on the size and quantity of crystals. Manufacturers have been able to provide a wide range of colors and shadows that even can be combined with metallic dyes and oxides so that dental technicians and dentists can match the natural color of the teeth.

A last property different from that the other ceramics is its biocompatibility.

In fact, favorable reactions of soft and hard dental tissues of the mouth have been observed against the use of disilicate. Foster et al., 2014, presented the results of an investigation in which observed that this ceramic material allowed the development and growth of fibroblasts, mainly due to its microscopic granular structure that allows it to have micro spaces between its molecules which would allow the overlapping of extensions cell between them ${ }^{36}$, which can be corroborated in alive observations since there have been no inflammatory reactions in the soft tissues surrounding the crowns and ceramic restorations of these materials in patients who are using them.

Unlike inflamed tissues that have been seen in hundreds of patients using crowns and bridges made of metal-porcelain or other restorative polymers.

\section{Microstructure}

They have a $30 \%$ vitreous phase $\left(\mathrm{SiO}_{2}, \mathrm{~K}_{2} \mathrm{O}\right.$, $\mathrm{MgO}, \mathrm{Al}_{2} \mathrm{O}_{3}, \mathrm{P}_{2} \mathrm{O}_{5}$ ) and $70 \%$ of crystals mainly in the form of microscopic needles of $\mathrm{li}$ thium disilicate $\left(\mathrm{Li}_{2} \mathrm{Si}_{2} \mathrm{O}_{5}\right)$ cross-linked between them ${ }^{37}$ and in turn submerged within the vitreous matrix.

Such microscopic crystals would be between 5 and $6 \mu \mathrm{m}$ long and 0.5 to $0.8 \mu \mathrm{m}$ thick ${ }^{38}$. The quality of these crystals has made this ceramic gain in resistance to frac- 
cia a la fractura debido a que estos cristales son capaces de permitir el avance de una microfisura en su paso por el interior de la cerámica haciendo que retarde y por lo tanto sea más difícil producir su rotura.

\section{Usos clínicos}

La cerámica de disilicato de litio se puede utilizar para la confección de carillas y facetas estéticas en dientes anteriores, inlays, onlays, coronas unitarias sin respaldo metálico tanto en el sector anterior, como en el sector posterior con muy buenos y durables resultados.

Se han reportado índices de éxito de entre 70 al $91 \%$ y supervivencia de hasta 10 años 39,40 .

Puentes de hasta tres unidades para reemplazo de piezas anteriores y hasta de 1 premolar, no siendo muy aconsejable todavía el reemplazo de molares.

\section{Procesamiento}

Las restauraciones dentales a base de disilicato se pueden obtener por medio de procedimientos de laboratorio de inyección y CAD CAM. ture because these crystals are capable of demanding to deflect the advance of a microfissure in its passage through the interior of the ceramic making it retard and therefore more difficult produce its break.

\section{Clinical uses}

Lithium disilicate ceramics can be used for the fabrication of veneers and aesthetic facets on anterior teeth, inlays, onlays, unitary crowns without metal backing both in the internal sector and in the back sector with very good and lasting results.

Success rates of between 70 to $91 \%$ and survival of up to 10 years have been reported $^{39,40}$.

Bridges of up to three units for replacement of previous parts and up to 1 premolar, it is not advisable to replace molars.

\section{Processing}

Dental restorations based on disilicate can be obtained by means of injection laboratory procedures and CAD CAM.

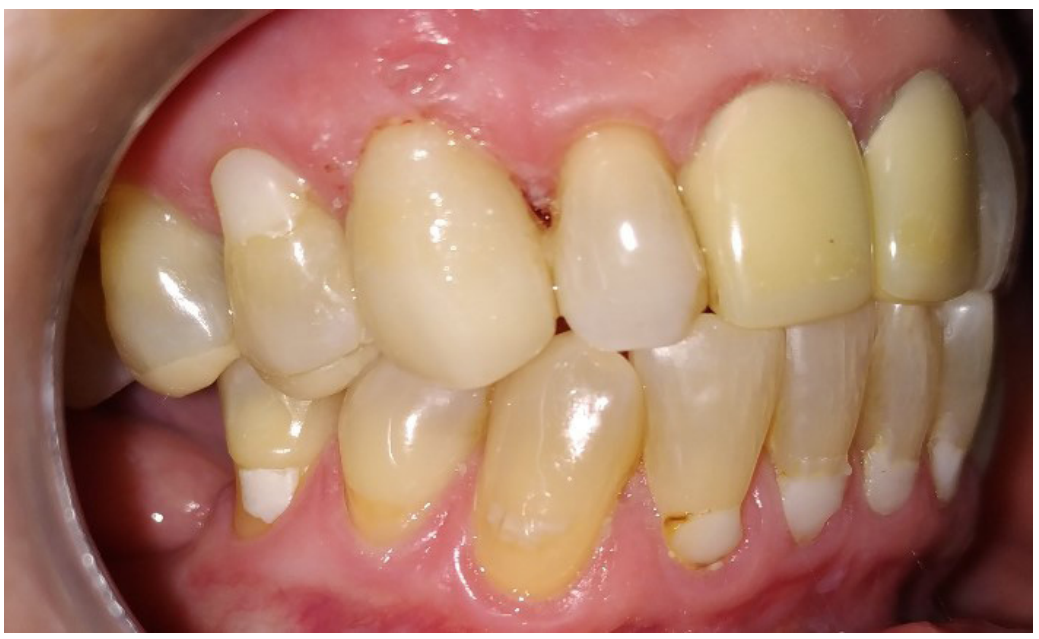

Figura 2. Corona de disilicato de litio pieza 13; Lithium disilicate crown piece 13

Nota: Se muestra la excelente translucidez y apariencia estética. Su notable adaptación biológica con los tejidos gingivales. Nótese el contraste con las coronas de metal-porcelana de las piezas 11 y 21. Así como la inflamación gingival después de años de uso de las mismas; Showing the excellent translucency and aesthetic appearance. Its remarkable biological adaptation with gingival tissues. Note the contrast with the metal-porcelain crowns of parts 11 and 21 . As well as gingival inflammation after years of use. 


\section{Ceramicas policristalinas}

Las cerámicas policristalinas ya no poseen fase vítrea, solamente una estructura interna cristalina, cuyos gránulos se encuentran muy unidos y apretados entre sí lo que las hace dueñas de una dureza y resistencia a la fractura superior a las anteriores cerámicas.

La zirconia y la alúmina son las representativas cerámicas de este grupo, sin embargo, debido las mejores propiedades mecánicas, la zirconia ha ido ganando mayor espacio dentro de la odontología, en los últimos diez años, a tal punto que la alumina ya no es fabricada.

\section{Zirconia tetragonal estabilizada por ítria (Y-TZP)}

El óxido de zirconium o zirconia $\left(\mathrm{ZRO}_{2}\right)$ ha sido conocido desde siglos atrás por los persas y los árabes quienes la llamaban ZARGON, palabra persa que se forma de dos vocablos ZAR que significa oro y GUM que significa color.

Debido a su extrema dureza y resistencia al desgaste se lo usaba y usa hasta hoy en la industria pesada, para fabricar herramientas de corte de otros materiales como rocas, metales, en la industria civil, en la fabricación de resistencias eléctricas de grandes centrales térmicas, en industrias químicas y mecánicas ${ }^{41}$.

En la década de los 70 se comenzó a introducirla en el campo médico, como biomaterial pero no fue hasta 1988 en un artículo científico por parte de Christel et al., donde se describe por primera vez su uso exitoso en el remplazo de cabezas de fémur desgastadas en pacientes con problemas de caderas ${ }^{42}$. Este éxito se debió principalmente a la gran resistencia al desgaste de este material, cuando fue comparado con el titanio que se usaba hasta entonces en este tipo de tratamientos. $Y$ a su biocompatibilidad al ser incapaz de producir reacciones inflamatorias en los tejidos óseos y musculares de los pacientes.

\section{Polycrystalline ceramics}

Polycrystalline ceramics don't have a vitreous phase, but they only have an internal crystalline structure, whose granules are very close and tight together, which makes them the owners of a hardness and fracture resistance superior to the previous ceramics.

Zirconia and alumina are the ceramic representatives of this group, however, due to the best mechanical properties, zirconia has been gaining more space within dentistry, in the last ten years, to the point that Alumina is no longer manufactured.

\section{Tetragonal zirconia stabilized by ítria (Y-TZP)}

Zirconium oxide or zirconia $\left(\mathrm{ZRO}_{2}\right)$ has been known for centuries by Persians and Arabs who called it ZARGON, a Persian word that is formed from two ZAR words that means gold and GUM that means color.

Due to its extreme hardness and wear resistance it was used and used until today in heavy industry, to manufacture tools for cutting other materials such as rocks, metals, in civil industry, in the manufacture of electrical resistors of large thermal power plants, in chemical and mechanical industries ${ }^{41}$.

In the 70s, it began to be introduced in the medical field, as a biomaterial, but it was not until 1988 in a scientific article by Christel et al., that it describes for the first time its successful use in the replacement of worn femur heads in patients with hip problems 42. This success was mainly due to the high wear resistance of this material, when compared to the titanium used until then in this type of treatment. And its biocompatibility being unable to produce inflammatory reactions in the bone and muscle tissues of patients. 
La entrada de la zirconia a la odontología se produjo hace unos quince años ${ }^{43}$ debido fundamentalmente a la presión de los odontólogos y de las personas de poder reemplazar los dientes perdidos con materiales que no fueran metálicos y que tuvieran una apariencia igual a los dientes naturales y que sean capaces de resistir las fuerzas y el desgaste masticatorio.

La zirconia tiene tres formas alotrópicas conocidas: la forma monoclínica (M) se encuentra a temperatura ambiente, con el incremento de la temperatura hasta los $1170^{\circ} \mathrm{C}$ se transforma a tetragonal $(\mathrm{T})$ mientras que temperaturas mayores a los $2370^{\circ} \mathrm{C}$ pasa a ser cúbica (C). Su punto de fusión se encuentra en los $2716^{\circ} \mathrm{C}^{44-46}$.

Para aumentar todavía más su resistencia mecánica, los científicos añadieron pequeñas cantidades de ciertos óxidos metálicos como el Itrio en proporciones de hasta un $3-4 \%$ logrando estabilizar su estado en la fase tetragonal, es por esta razón que se la conoce como Zirconia Parcialmente Estabilizada por Itria, o Y-TZP ${ }^{41}$.

A diferencia de todas las cerámicas anteriores, esta última no presenta ninguna fase o matriz vítrea, por lo tanto ya no sería ácido-débil, sino más bien pertenece al grupo de las ácido-resistentes. En las cuales el ataque con ácido fluorhídrico (HF) no tiene razón de ser ${ }^{47-49}$.

Debido a sus excelentes propiedades mecánicas, ha sido llamada el acero cerámi$\mathrm{co}^{50}$. Y por su nulo intercambio iónico se dice que es inerte químicamente lo cual la hace perfecta para realizar con ella restauraciones dentales que no provoquen irritación ni daño a los tejidos dentales ${ }^{51}$.

Algunas marcas comerciales más representativas de zirconia son: In-Ceram Zirconia (IZ) (Vita Zahnfabrik, Bad Sackingen, Germany), DC Zirkon (DZ) (DCS Dental AG, Allschwil, Switzerland) y Lava Plus (3M ESPE, St.Paul, MN; EEUU).
The entrance of zirconia to dentistry occurred about fifteen years ago ${ }^{43}$, mainly due to the pressure of dentists and people to be able to replace lost teeth with materials that were not metallic and that looked the same as natural teeth and that are able to resist the forces and the masticatory wear.

Zirconia has three known allotropic forms: the monoclinic form (M) is at room temperature, with the increase in temperature to $1170^{\circ} \mathrm{C}$ it becomes tetragonal $(\mathrm{T})$ while temperatures greater than $2370^{\circ} \mathrm{C}$ become $\mathrm{cu}$ bic (C) Its melting point is found at $2716^{\circ} \mathrm{C}^{44-}$ 46.

To further increase its mechanical strength, the scientists added small amounts of certain metal oxides such as Itrium in proportions of up to $3-4 \%$, stabilizing its state in the tetragonal phase, that's why it is known as Partially Stabilized Zirconia by Itria, or Y-TZP41.

Unlike all previous ceramics, the latter does not present any glass phase or matrix, therefore it would no longer be weak-acid, but rather belongs to the group of resistant-acid. In which the attack with hydrofluoric acid (HF) has no reason to be b7-49. $^{47}$

Due to its excellent mechanical properties, it has been called steel ceramic ${ }^{50}$. And because of its zero ion exchange, it is said to be chemically inert, which makes it perfect for dental restorations that do not cause irritation or damage to dental tissues ${ }^{51}$.

Some of the most representative trademarks of zirconia are: In-Ceram Zirconia (IZ) (Vita Zahnfabrik, Bad Sackingen, Germany), DC Zirkon (DZ) (DCS Dental AG, Allschwil, Switzerland) and Lava Plus (3M ESPE, St.Paul, MN; USA). 
Dentro de las propiedades mecánicas más interesantes se destacan su alta tenacidad a la fractura entre 7 a $10 \mathrm{MPa} \cdot \mathrm{m} 1 / 2$, su resistencia flexural de entre 680 a $1200 \mathrm{Mpa}$, su módulo elástico, similar a algunas aleaciones metálicas $240 \mathrm{GPa}$ y una dureza de $13 \mathrm{GPa}^{52}$, valores superiores hasta en 5 o 6 veces más que las otras cerámicas.

Mientras que tiene gránulos de zirconia en forma de finas partículas que varían de tamaño y pueden presentar menos de $1 \mu$ de espesor aglomerados y fuertemente unidos por sus bordes dejando espacios de menos de 0,3 $\mu$ o menos en donde se localizan porosidades que apenas suman un $1 \%$ o menos de su volumen total ${ }^{52}$. Lo que explica su alta dureza.

La Y-TZP es considerada un material inteligente debido a que es capaz de evitar que una microfractura avance por medio del grosor de su cuerpo cuando está sometido a stress y termine quebrándola.

Este fenómeno se debe al hecho de que cuando una fisura o un defecto se hace presente en su superficie, los cristales de zirconia estabilizada cambian de estado tetragonal para monoclínico; con cada cambio de estado sus gránulos aumentan de volumen entre un 4 a $5 \%$ produciendo un efecto de compresión sobre la fisura obstaculizando el avance de esta ${ }^{53}$ (figura 3).
Among the most interesting mechanical properties are its high fracture toughness between 7 to $10 \mathrm{MPa}$.m1 / 2, its flexural strength between 680 to $1200 \mathrm{Mpa}$, its elastic modulus, similar to some $240 \mathrm{GPa}$ metal alloys and a hardness of $13 \mathrm{GPa}^{52}$, higher values up to 5 or 6 times more than the other ceramics.

While it has granules of zirconia in the form of fine particles that vary in size and can have less than $1 \mu$ thick and agglomerated together by their edges leaving spaces of less than $0.3 \mu$ or less where porosities that barely add up to 1 are located \% or less of its total volume ${ }^{52}$. Which explains its high hardness.

The Y-TZP is considered an intelligent material because it is able to prevent a microfracture from advancing through the thickness of your body when it is under stress and ends up breaking it.

This phenomenon is due to the fact that when a fissure or defect is present on its surface, stabilized zirconia crystals change from tetragonal to monoclinic; with each change of state their granules increase in volume by 4 to $5 \%$ producing a compression effect on the fissure, hindering the advance of this ${ }^{53}$ (figure 3 ).

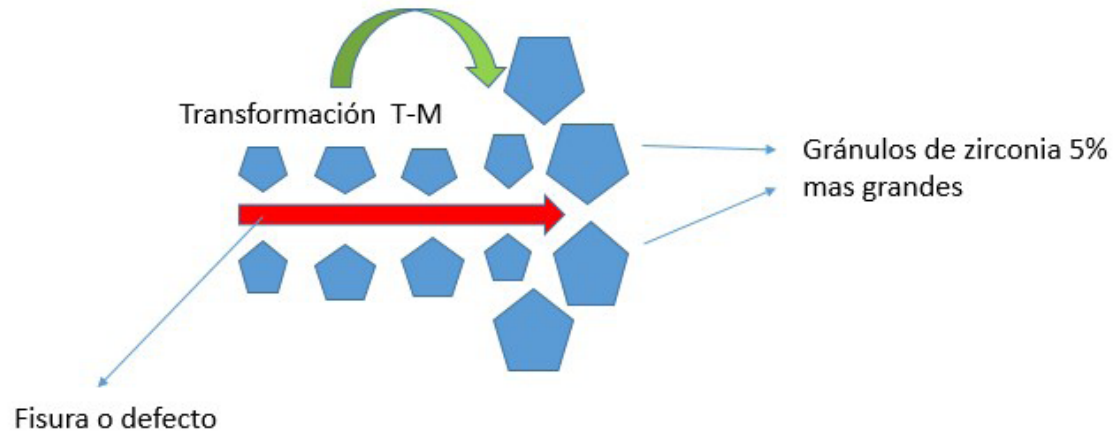

Figura 3. Muestra la transformación de la fase tetragonal para monoclínica de la Y-YTZP al experimentar la presencia de un defecto (en rojo) inducido por un factor externo, lo que produce un aumento del volumen de los cristales de zirconia en un $5 \%$ que aumentan la presión sobre la fisura, dificultando su avance; shows the transformation of the tetragonal phase for Y-YTZP monoclinic when experiencing the presence of a defect (in red) induced by an external factor, which produces an increase in the volume of zirconia crystals by $5 \%$ which they increase the pressure on the fissure, hindering its advance. 
En cuanto a sus propiedades ópticas, tiene un color blanco opaco debido a que los gránulos están muy cohesionados entre sí. Lo que dificulta el paso de la luz, por lo que ella no es reflejada y menos trasmitida por medio de su espesor, produciendo un gran efecto de dispersión de la misma.

Investigaciones afirman que en comparación con el disilicato de litio, la Y-TZP solo tiene una translucencia del $70 \%{ }^{54,55}$.

Sin embargo, el color blanco característico de ella la hace muy útil a momento de querer igualar al color de los dientes naturales.

Recientemente, los investigadores han propuesto alteraciones de las piezas totalmente cerámicas en zirconia con reducción del tamaño de los gránulos y el aumento de la fase cúbica que vuelve a la zirconia más translúcida.

Por su inercia química muchos investigadores sugieren realizar tratamientos en la superficie interna de ella para mejorar su adhesión. Tratamientos como el arenado triboquímico (Sistema Cojet o Rocatec 3M ESPE, St.Paul, MN; EEUU) es actualmente el gold estándar cuando de adherirla con cementos resinosos se trata ${ }^{56-58}$.

Debido a la capa de oxígeno que contamina su superficie, se está usando con mucho éxito, sistemas adhesivos que contienen monómeros ácidos-fosfatados, particularmente el 10 MDP que ha demostrado que ser capaz de unirse químicamente a su superficie $e^{59-61}$.

\section{Microestructura}

Está compuesta por cristales en forma de gránulos de forma tetragonal, lo que se conoce con el nombre de fase metaestable tetragonal $(T)$ estos gránulos son estables a temperatura ambiente porque los fabricantes le adicionan 2-5\% mol \% de óxido de Itria $\left(\mathrm{Y}_{2} \mathrm{O}_{3}\right)^{44}$.

Producto de la ausencia de sílica en su estructura interna ella no posee un intercam-
As for its optical properties, it has an opaque white color because the granules are very cohesive with each other. What hinders the passage of light, so it is not reflected and less transmitted through its thickness, producing a great effect of dispersion of it.

Research states that compared to lithium disilicate, Y-TZP only has a translucency of $70 \% 54,55$.

However, the characteristic white color of it makes it very useful when wanting to match the color of natural teeth.

Recently, researchers have proposed alterations of the totally ceramic pieces in zirconia with reduced granule size and an increase in the cubic phase that returns to the more translucent zirconia.

Due to its chemical inertia, many researchers suggest carrying out treatments on the internal surface of it to improve its adhesion. Treatments such as tribochemical sandblasting (Cojet System or Rocatec 3M ESPE, St.Paul, MN; USA) is currently the gold standard when adhering with resinous cements is treated ${ }^{56-58}$.

Due to the oxygen layer that contaminates its surface, adhesive systems containing acid-phosphated monomers, particularly the MDP that has been shown to be able to chemically bond to its surface ${ }^{59-61}$, are being used with great success.

\section{Microstructure}

It is composed of crystals in the form of granules of tetragonal form, which is known as the tetragonal metastable phase $(T)$ these granules are stable at room temperature because manufacturers add $2-5 \%$ mol\% of Itria oxide $\left(\mathrm{Y}_{2} \mathrm{O}_{3}\right)^{44}$.

Due to the absence of silica in its internal structure, it does not have an ion exchan- 
bio iónico62 razón por la cual no es posible realizar un grabado ácido con HF al momento de intentar hacer un procedimiento de adhesión.

\section{Usos clínicos}

Por sus excelentes propiedades mecánicas y ópticas se pueden hacer restauraciones protésicas extensas, puentes de más de 3 unidades, coronas y prótesis sobre implantes, implantes, brackets de ortodoncia, postes endodónticos, incrustaciones inlays y onlays.

\section{Procesamiento}

Se pueden obtener restauraciones por medio de procedimientos de CAD CAM, seguido de sinterización. $\mathrm{ge}^{62}$, which is why it is not possible to perform an acid etch with HF when trying to make an adhesion procedure.

\section{Clinical uses}

Due to its excellent mechanical and optical properties, extensive prosthetic restorations, bridges of more than 3 units, crowns and prostheses on implants, implants, orthodontic brackets, endodontic posts, inlays and onlays can be made.

\section{Processing}

Restorations can be obtained through CAD CAM procedures, followed by sintering.

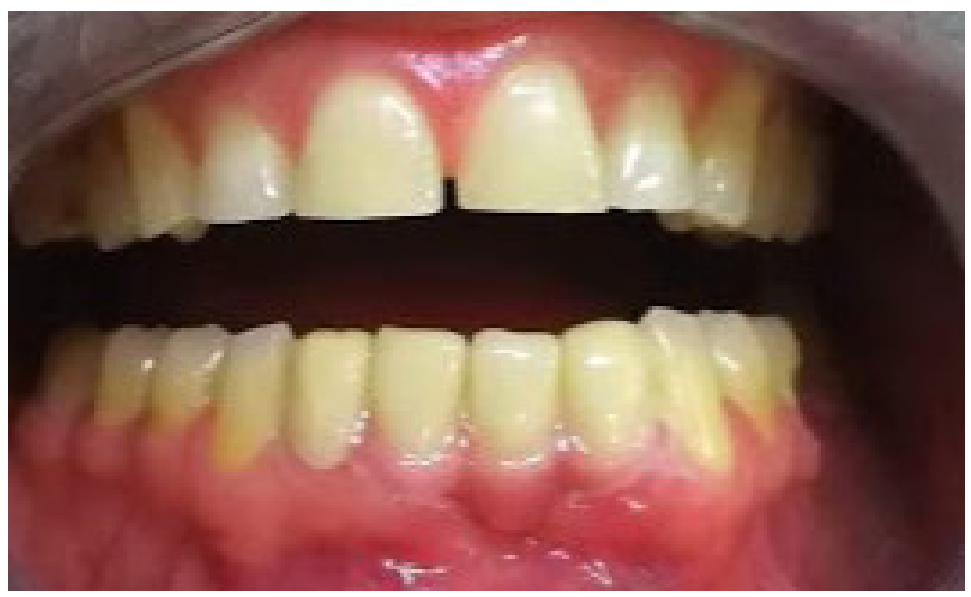

Figura 4. Puente de Y-TZP recubierta con cerámica feldespática (VM9) de piezas 32-42 mostrando muy buena integración y estética con sus dientes vecinos; Y-TZP bridge covered with feldspathic ceramic (VM9) of pieces 32-42 showing very good integration and aesthetics with its neighboring teeth.

\section{Cerámicas híbridas (compositos di- ferenciados y especiales)}

El desarrollo del CAD CAM en los últimos años ha permitido también la búsqueda y evolución de nuevos materiales cerámicos capaces de compensar algunas de las deficiencias en las propiedades mecánicas y físicas de las cerámicas actuales.

Como hemos visto hasta ahora, los diversos materiales cerámicos, son esencialmente inorgánicos, que llevan en su composición
Hybrid ceramics (differentiated and special composites)

The development of CAD CAM in recent years has also allowed the search and evolution of new ceramic materials capable of compensating for some of the deficiencies in the mechanical and physical properties of current ceramics.

As we have seen so far, the various ceramic materials are essentially inorganic, which carry in their internal composition various 
interna diversas proporciones de fases vítreas y/o cristalinas que les proporcionan distintos grados de dureza, resistencia a la fractura, resistencia al desgaste, así como también distintos niveles de translucidez, opalescencia y fluorescencia.

Sin embargo, no siempre es posible encontrar una cerámica con las propiedades ideales, por ejemplo, una zirconia con alto contenido cristalino será más dura y resistente a la fractura que las demás, pero en cambio será más difícil de cementar. Una feldespática, que puede tener estupendas propiedades ópticas, pero en cambio si no está bien pulida puede tener un alto potencial de desgaste de los dientes antagonistas.

Los composites se han usado durante décadas para la restauración estética de los dientes cariados, o fracturados con excelentes resultados. Sin embargo todavía persisten muchos problemas con ellos, especialmente la contracción que sufren durante su polimerización, pobres propiedades mecánicas y poca resistencia al desgaste ${ }^{63}$.

Esto ha llevado a muchos investigadores de todo el mundo a desarrollar un material que conjugue lo mejor de estos dos elementos para que se convierta en una nueva alternativa al momento de restaurar los dientes.

La compañía VITA lanzó al mercado en 2011, un material Ilamado VITA ENAMIC (Zahnfabrik, Bad Säckingen, Germany) que fue descrito por sus fabricantes como una cerámica porosa de vidrio infiltrada por polímeros. Debido a ello son conocidos como $\mathrm{PICN}^{64}$ (polymer infiltrated cerámics network).

Estas cerámicas tienen un $86 \%$ de fase vítrea y un $14 \%$ de polímero, infiltrado a diferentes presiones y temperaturas, para obtener cerámicas de diferentes densidades, con el objeto de ir mejorando tanto sus cualidades mecánicas como ópticas ${ }^{63,65}$.

Obteniendo con ello por primera vez un ma- proportions of vitreous and/or crystalline phases that provide them with different degrees of hardness, fracture resistance, wear resistance, as well as different levels of translucency, opalescence and fluorescence.

However, it is not always possible to find a ceramic with the ideal properties, for example a zirconia with a high crystalline content will be harder and resistant to fracture than the others, but instead it will be more difficult to cement. A feldspathic, which can have great optical properties, but if it is not well polished, it can have a high wear potential of the opposing teeth.

The composites have been used for decades for the aesthetic restoration of decayed teeth, or fractured with excellent results. However, there are still many problems with them, especially the contraction they suffer during polymerization, poor mechanical properties and poor wear resistance ${ }^{63}$.

This has led many researchers around the world to develop a material that combines the best of these two elements so that it becomes a new alternative when restoring teeth.

The VITA company launched in 2011, a material called VITA ENAMIC (Zahnfabrik, Bad Säckingen, Germany) that was described by its manufacturers as a porous glass ceramic infiltrated by polymers. Because of this they are known as PICN ${ }^{64}$ (polymer infiltrated ceramics network).

These ceramics have $86 \%$ glass phase and $14 \%$ polymer, infiltrated at different pressures and temperatures, to obtain ceramics of different densities, in order to improve both their mechanical and optical qualities ${ }^{63,65}$.

Obtaining with it for the first time a restorati- 
terial restaurador con las mismas características del esmalte y la dentina.

Posterior a este lanzamiento, se han presentado en el mercado odontológico bloques nanocerámicos de resina compuesta reforzadas con nano relleno como es el caso de Lava Ultimate (3M ESPE) ${ }^{66}$, o de rellenos nano híbridos como Cerasmart (GC Europe), Brava Block (FGM, Joinville. Santa Catarina, Brasil), entre otros.

\section{Propiedades mécanicas y ópticas}

Ellas presentan una resistencia flexural de hasta $160 \mathrm{MPa}$, esto es la mitad de lo que alcanzan los disilicatos de litio, pero tres veces más de lo que tienen las feldespáticas. De igual manera cuando comparados con la resistencia a la flexión de los polímeros que se encuentra en alrededor de $130 \mathrm{MPa}$, se puede observar que este valor aumenta en las PICN.

Esto se consigue porque los poros de la cerámica son rellenados, al momento de la infiltración, por el polímero, y cuando una fuerza intenta deformar al cuerpo, este reacciona concentrando el stress en la zona polimérica, mucho más elástica, que la fase cerámica y de esta manera es capaz de disipar las fuerzas que podrían romperlo. Esta es la misma razón por la cual tienen un módulo elástico de 16-28,1 GPa que es mucho mayor que las otras cerámicas y composites $^{64}$.

Es muy bien conocido que las feldespáticas y los disilicatos no soportan una deformación más allá del 0,1 al 0,2\% antes de fracturarse, por lo tanto son frágiles, pero las PICN son capaces de resistir tensiones de deformación hasta del 4,1\% antes de romperse. Lo cual mejoraría la vida clínica de las restauraciones porque si es capaz de soportar altas deformaciones es muy posible que soporte muy bien las cargas masticatorias.

Resulta interesante también anotar que el módulo elástico de la dentina esta entre 16 ve material with the same characteristics of enamel and dentin.

Subsequent to this launch, nano-ceramic blocks of composite resin reinforced with nano fillers have been launched on the dental market, such as Lava Ultimate (3M ESPE) ${ }^{66}$, or nano-hybrid fillers such as Cerasmart (GC Europe), Brava Block (FGM, Joinville. Santa Catarina, Brazil), among others.

\section{Mechanical and optical properties}

They have a flexural resistance of up to 160 $\mathrm{MPa}$, this is half of what lithium disilicates reach, but three times more than feldspathic ones have. Similarly when compared to the flexural strength of polymers that is around $130 \mathrm{MPa}$, it can be seen that this value increases in the PICN.

This is achieved because the pores of the ceramic are filled, at the time of infiltration, by the polymer, and when a force tries to deform the body, it reacts by concentrating the stress in the polymeric zone, much more elastic, than the ceramic phase and In this way it is able to dissipate the forces that could break it. This is the same reason why they have an elastic modulus of 16-28.1 GPa that is much larger than the other ceramics and composites ${ }^{64}$.

It is very well known that feldspathic and disilicates do not withstand deformation beyond 0.1 to $0.2 \%$ before fracturing, therefore they are fragile, but PICNs are capable of withstanding deformation stresses up to 4.1 $\%$ before breaking. Which would improve the clinical life of the restorations because if it is able to withstand high deformations it is very possible that it supports very well the masticatory loads.

It is also interesting to note that the elastic dentin module is between 16 and 20.3 
al 20,3 GPa, muy similar a los $16-28,1$ de las PICN, lo que favorecería la presencia de un stress más uniforme entre estos dos sustratos cuando estén unidos por medio de un agente adhesivo, al momento de soportar las cargas masticatorias.

En cuanto a sus propiedades ópticas, sin bien es cierto que los fabricantes proveen una gama grande de colores y brillos, con capas de resina transparente y opaca que intentan asemejarse a la dentina y al esmalte, hasta hoy en día, las PICN no consiguen igualar las características ópticas de los dientes naturales ${ }^{67}$.

A diferencia de las otras cerámicas, en estas se observa una pérdida de brillo con el paso del tiempo.

\section{Microestructura}

Estos materiales se fabrican a altas temperaturas y altas presiones, razón por la cual alcanzan altos porcentajes de grados de conversión (85\%) lo cual mejora notablemente sus propiedades mecánicas ${ }^{68}$ siguiendo dos pasos: primero una red de cerámica vítrea y porosa es producida y acondicionada por un agente de enlace. Segundo, la fase vítrea de la cerámica es reemplazada y al mismo tiempo infiltrada con un polímero por acción capilar ${ }^{64,65}$.

Para producir una PICN los fabricantes manipulan el tamaño de la partícula de cerámica, utilizando diferentes temperaturas de cocción, entonces es tratada químicamente con un agente de enlace generalmente un silano, para luego rellenar sus poros con UDMA, TEDMA e otros monómeros de metacrilato, que serán sometidos a calor para que polimericen dentro del esqueleto de ella ${ }^{64}$.

Esto permite la formación de dos fases distintas: la una cerámica y la otra polimérica, que reemplaza a la frágil fase vítrea de las demás cerámicas.

Este nuevo elemento así formado tendrá entonces una reducida fragilidad y rígidez
GPa, very similar to the 16-28.1 of the PICN, which would favor the presence of a more uniform stress between these two substrates when they are joined by means of an adhesive agent, when supporting the masticatory loads.

As for its optical properties, it is true that manufacturers provide a large range of colors and glare, with layers of transparent and opaque resin that try to resemble dentin and enamel, until today, the PICN can not match the optical characteristics of natural teeth ${ }^{67}$.

Unlike the other ceramics, there is a loss of brightness in these over time.

\section{Microstructure}

These materials are manufactured at high temperatures and high pressures, which is why they reach high percentages of degrees of conversion $(85 \%)$ which greatly improves their mechanical properties ${ }^{68}$ by following two steps: first a network of vitreous and porous ceramic is produced and conditioned by a bonding agent. Second, the vitreous phase of the ceramic is replaced and at the same time infiltrated with a polymer by capillary action ${ }^{64,65}$.

To produce a PICN manufacturers manipulate the size of the ceramic particle, using different cooking temperatures, then it is chemically treated with a bonding agent usually a silane, and then fill its pores with UDMA, TEDMA and other methacrylate monomers, which they will be subjected to heat so that they polymerize inside her skeleton ${ }^{64}$.

This allows the formation of two distinct phases: the one ceramic and the other polymeric, which replaces the fragile vitreous phase of the other ceramics.

This new element thus formed will then have a reduced fragility and stiffness along with 
junto con una mejorada resistencia a la fractura y una adecuada dureza para ser trabajada con más facilidad en el CAD CAM.

El potencial de desgaste o abrasión de las PICN con los dientes naturales antagonistas es mucho menor que el de las cerámicas vítreas.

\section{Usos clínicos}

A pesar de sus limitaciones en sus propiedades ópticas a largo plazo, con estos nuevos materiales se viene realizando, coronas unitarias, incrustaciones, inlays, onlays, overlays, coronas sobre implantes y restauraciones adhesivas con la técnica de mínima preparación o mínimo desgaste en zonas de dientes anteriores para reemplazar un único diente ${ }^{69}$.

Sin embargo se necesitan más estudios clínicos a largo plazo de comparación de las PICN frente a otras cerámicas dentales.

\section{Procesamiento}

Se pueden obtener piezas por medio del CAD CAM, seguido de polimerización, que puede ser de alta temperatura y alta presión (HT-HP).

\section{Discusión}

Desde su aparecimiento en 1960, las cerámicas dentales han experimentado una indudable evolución y cambio tanto de sus propiedades mecánicas como ópticas, para asemejarse a un diente natural en su color, en su textura y en su resistencia al desgaste y a las fuerzas masticatorias.

Las primeras porcelanas fueron las feldespáticas que al ser obtenidas de la fusión del feldespato por medio de un proceso de tratamiento térmico a altas temperaturas (800 a $1200^{\circ} \mathrm{C}$ ) son capaces de formar un elemento vidrioso, que contiene núcleos cristalinos de leucita ${ }^{2}$. Estas dos fases hacen que dichas porcelanas tengan unas excelentes características ópticas, pero malas condiciones mecánicas, por lo tanto son incapaces de resistir las fuerzas de oclusión an improved fracture resistance and adequate hardness to be more easily worked in the CAD CAM.

The potential for wear or abrasion of PICN with antagonistic natural teeth is much less than that of vitreous ceramics.

\section{Clinical uses}

In spite of its limitations in its long-term optical properties, with these new materials, unit crowns, inlays, inlays, onlays, overlays, crowns on implants and adhesive restorations are being made with the technique of minimum preparation or minimum wear in areas of anterior teeth to replace a single tooth ${ }^{69}$.

However, more long-term clinical studies are needed to compare the PICN versus other dental ceramics.

\section{Processing}

Parts can be obtained through CAD CAM, followed by polymerization, which can be high temperature and high pressure (HT$\mathrm{HP})$.

\section{Discussion}

Since its appearance in 1960, dental ceramics have undergone an undoubted evolution and change of both their mechanical and optical properties, to resemble a natural tooth in its color, texture and resistance to wear and masticatory forces.

The first porcelains were feldspathic which, when obtained from the fusion of feldspar by means of a heat treatment process at high temperatures $\left(800\right.$ to $1200^{\circ} \mathrm{C}$ ), are capable of forming a glassy element, which contains crystalline leucite nuclei ${ }^{2}$. These two phases make these porcelains have excellent optical characteristics, but poor mechanical conditions, therefore they are incapable of resisting occlusion forces and require mechanical support to survive in the mouth. 
y requieren un respaldo mecánico para poder sobrevivir en la boca. Son las que se usan para fabricar coronas y puentes de metal-porcelana.

Hoy en día gracias a los avances notables de los adhesivos dentales, estas porcelanas pueden ser usadas en los incisivos y caninos, cuando se trata de hacer unas carillas estéticas, con la condición de que estén adheridas al esmalte dental ${ }^{17}$.

No tienen buenos resultados cuando están soportadas por dentina.

Las leucitas, tienen núcleos cristalinos más grandes que las porcelanas anteriores y tienen una fase vítrea en menor proporción lo que las hace más resistentes y con buenas propiedades mecánicas. Son muy útiles para hacer carillas en dientes anteriores, de la misma manera deben estar siempre adheridas a esmalte. Al igual que las feldespáticas son utilizadas en las Ilamadas "carillas o lentes de contacto" Pero todavía estas tienen altos índices de fracaso o fractura cuando se hacen coronas y puentes dentales.

Las cerámicas vítreas de disilicato de lítio ya poseen en su interior cristales mucho más largos y grandes de disilicato que están rodeadas por una matriz vítrea ${ }^{31}$. Pero esta estructura así formada es el resultado de un proceso que se llama de ceramización el cual permite a los fabricantes modificar y mejorar las propiedades de resistencia mecánica de estas variando la temperatura de cocción y con ello logran producir un material cerámico casi sin microporos.

Con todas estas condiciones, los disilicatos de litio, son capaces de resistir y tolerar fuerzas masticatorias de hasta $400 \mathrm{Mpa}$. Con lo cual ya se podrían hacer coronas totales sin metal en zonas de premolares y puentes de hasta tres unidades en anteriores con muy buenos resultados a largo plazo ${ }^{40}$.

Por último, las cerámicas cristalinas como las zirconias, no presentan una matriz vítrea,
They are the ones used to make crowns and bridges made of metal-porcelain.

Nowadays, thanks to the remarkable advances of dental adhesives, these porcelains can be used in the incisors and canines, when it comes to making aesthetic veneers, with the condition that they are attached to dental enamel ${ }^{17}$.

They do not have good results when they are supported by dentin.

The leucites have crystalline nuclei larger than the previous porcelains and have a vitreous phase in a smaller proportion which makes them more resistant and with good mechanical properties. They are very useful for veneers on anterior teeth, in the same way they must always be adhered to enamel. Like feldspats, they are used in the so-called "contact lens veneers". But they still have high rates of failure or fracture when crowns and dental bridges are made.

Vitreous lithium disilicate ceramics already have much longer and larger disilicate crystals inside them that are surrounded by a vitreous matrix ${ }^{31}$. But this structure thus formed is the result of a process called ceramization which allows manufacturers to modify and improve their mechanical resistance properties by varying the cooking temperature and thereby produce a ceramic material almost without micropores.

With all these conditions, lithium disilicates are able to resist and tolerate chewing forces of up to $400 \mathrm{Mpa}$. With which you could already make total crowns without metal in areas of premolars and bridges of up to three units in previous ones with very good long-term results ${ }^{40}$.

Finally, crystalline ceramics such as zirco- 
sino que ellas solo están conformadas por la unión casi perfecta de cristales de zirconio, que además tiene la característica única de que cuando son sometidos a stress o un estímulo externo que intentan dañarlas, estas se transforman de su fase tetragonal a una monoclínica ${ }^{52}$. Este fenómeno único en los materiales cerámicos, viene acompañado de un aumento de su volumen en un $5 \%$. Lo que comprime el avance de cualquier microfisura que se haya formado internamente, impidiendo su camino, haciendo más difícil la fractura del material.

Todas estas características hacen de ella un cuerpo muy duro, y altamente resistente.

Por esta razón con ellas ya se pueden hacer puentes grandes en zonas posteriores, coronas individuales, y estructuras para implantes, incluso implantes mismo. Pero hace muy difícil su cementación.

La técnica correcta para adherir una pieza de Y-TZP al diente pasa por el uso de un arenado triboquímico, seguido de silanos y adhesivos a base de monómeros fosfato ácidos. (10 MDP) 58 .

\section{Conclusiones}

Las cerámicas dentales poco a poco han ido superando sus limitaciones hasta el punto de convertirse en elementos restauradores muy buscados por los odontólogos, pacientes, y técnicos dentales.

Hoy en día existen varios tipos de cerámicas, cada una con diferentes características las cuales permiten al odontólogo rehabilitar dientes con excelente naturalidad.

Existen estudios clínicos a largo plazo de muchas de estas cerámicas, en otros países, sin embargo en nuestro país no tenemos datos que nos confirmen o descarten dichos resultados, sería de mucha utilidad científica desarrollar investigaciones en nuestro medio. nias do not have a vitreous matrix, but they are only made up of the almost perfect union of zirconium crystals, that also has the unique characteristic that when they are subjected to stress or an external stimulus that they try to damage them, they are transformed from their tetragonal phase to monocli$\mathrm{nic}^{52}$. This unique phenomenon in ceramic materials is accompanied by an increase in volume by $5 \%$. What compresses the advance of any microfissure that has formed internally, preventing its path, making the fracture of the material more difficult.

All these characteristics make it a very hard, and highly resistant body.

For this reason, large bridges can now be made in posterior areas, individual crowns, and implant structures, including implants. But it makes cementation very difficult.

The correct technique to adhere a piece of Y-TZP to the tooth involves the use of a tribochemical sandblasting, followed by silanes and adhesives based on acidic phosphate monomers. (10 MDP) 58 .

\section{Conclusions}

Dental ceramics have gradually overcome their limitations to the point of becoming highly sought after restorative elements by dentists, patients, and dental technicians.

Today there are several types of ceramics, each with different characteristics which allow the dentist to rehabilitate teeth with excellent naturalness.

There are long-term clinical studies of many of these ceramics, in other countries, however in our country we do not have data to confirm or discard these results, it would be very useful to develop research in our environment. 


\section{Bibliografía}

1. Rosenblum MA, Schulman A. A Review of All-Ceramic Restorations. The Journal of the American Dental Association. 1997;128(3):297-307.

2. Cesar P. Cerâmicas odontológicas. Acedido em. 2011;13(05).

3. Shenoy A, Shenoy N. Dental ceramics: An update. Journal of conservative dentistry: JCD. 2010;13(4):195.

4. Craig RG, Powers JM. Materiais dentários restauradores: Santos; 2004.

5. Gomes E, Assunção W, Rocha E, Santos P. Ceramic in dentistry: current situation. Cerâmica. 2008;54(331):319-25.

6. Gracis S, Thompson VP, Ferencz JL, Silva NR, Bonfante EA. A new classification system for all-ceramic and ceramic-like restorative materials. International Journal of prosthodontics. 2015;28(3)

7. Denry IL. Recent Advances in Ceramics for Dentistry. Critical Reviews in Oral Biology \& Medicine. 1996;7(2):134-43.

8. Al-Harthi AA, Aljoudi M, Almaliki M, El-Banna K. Laboratory Study of Micro-shear Bond Strength of Two Resin Cements to Leucite Ceramics using Different Ceramic Primers. The journal of contemporary dental practice. 2018;19(8):918-24.

9. Stangel I, Nathanson D, Hsu C. Shear strength of the composite bond to etched porcelain. Journal of dental research. 1987;66(9):1460-5.

10. Spohr AM, Sobrinho LC, Consani S, Sinhoreti MAC, Knowles JC. Influence of surface conditions and silane agent on the bond of resin to IPS Empress 2 ceramic. International Journal of Prosthodontics. 2003;16(3).

11. Cesar PF, Yoshimura HN, Júnior WGM, Okada CY. Correlation between fracture toughness and leucite content in dental porcelains. Journal of dentistry. 2005;33(9):721-9.

12. Morena R, Lockwood P, Fairhurst $C$. Fracture toughness of commercial dental porcelains. Dental Materials. 1986;2(2):58-62.

13. Cattell MJ, Chadwick TC, Knowles JC, Clarke $\mathrm{RL}$, Lynch E. Flexural strength optimisation of a leucite reinforced glass ceramic. Dental Materials. 2001;17(1):21-33.

14. Denry IL, Mackert JR, Holloway JA, Rosenstiel SF. Effect of Cubic Leucite Stabilization on the Flexural Strength of Feldspathic Dental Porcelain. Journal of dental research. 1996;75(12):1928-35.

15. Cattell MJ, Clarke RL, Lynch EJR. The transverse strength, reliability and microstructural features of four dental ceramics - Part I. Journal of Dentistry. 1997;25(5):399-407.
16. Quinn J, Sundar V, Lloyd IK. Influence of microstructure and chemistry on the fracture toughness of dental ceramics. Dental Materials. 2003;19(7):603-11.

17. Gresnigt MM, Cune MS, Schuitemaker J, van der Made SA, Meisberger EW, Magne P, et al. Performance of ceramic laminate veneers with immediate dentine sealing: An 11 year prospective clinical trial. Dental Materials. 2019;35(7):1042-52.

18. Beier US, Kapferer I, Burtscher D, Dumfahrt H. Clinical performance of porcelain laminate veneers for up to 20 years. International Journal of Prosthodontics. 2012;25(1):79-85.

19. Layton DM, Walton TR. The up to 21-year clinical outcome and survival of feldspathic porcelain veneers: accounting for clustering. International Journal of Prosthodontics. 2012;25(6).

20. Ong JL, Farley DW, Norling BK. Quantification of leucite concentration using X-ray diffraction. Dental Materials. 2000;16(1):20-5.

21. Mackert Jr J, Williams A. Microcracks in dental porcelain and their behavior during multiple firing. Journal of dental research. 1996;75(7):1484-90.

22. Mackert Jr J, Rueggeberg E, Lockwood P, Evans A, Thompson W. Isothermal anneal effect on microcrack density around leucite particles in dental porcelain. Journal of dental research. 1994;73(6):1221-7.

23. Mackert JR, Williams AL, Ergle JW, Russell CM. Water-enhanced crystallization of leucite in dental porcelain. Dental Materials. 2000;16(6):42631.

24. Morena R, Lockwood PE, Fairhurst CW. Fracture toughness of commercial dental porcelains. Dental Materials. 1986;2(2):58-62.

25. Kon M, Kawano F, Asaoka K, Matsumoto N. Effect of Leucite Crystals on the Strength of Glassy Porcelain. Dental Materials Journal. 1994;13(2):13847,269 .

26. Maunula H, Hjerppe J, Lassila LL, Närhi T. Optical Properties and Failure Load of Thin CAD/ CAM Ceramic Veneers. The European journal of prosthodontics and restorative dentistry. 2017;25(2):86-92.

27. Kelly JR, Benetti P. Ceramic materials in dentistry: historical evolution and current practice. Australian dental journal. 2011;56:84-96.

28. Krämer N, Taschner M, Lohbauer U, Petschelt A, Frankenberger $\mathrm{R}$. Totally bonded ceramic inlays and onlays after eight years. Journal of Adhesive Dentistry. 2008;10(4).

29. Zarone F, Di Mauro MI, Ausiello P, Ruggiero G, Sorrentino R. Current status on lithium disilicate and zirconia: a narrative review. BMC Oral Health. $2019 ; 19(1): 134$. 
30. Albakry M, Guazzato M, Swain MV. Influence of hot pressing on the microstructure and fracture toughness of two pressable dental glass-ceramics. Journal of Biomedical Materials Research Part B: Applied Biomaterials: An Official Journal of The Society for Biomaterials, The Japanese Society for Biomaterials, and The Australian Society for Biomaterials and the Korean Society for Biomaterials. 2004;71(1):99-107.

31. Zarone F, Ferrari M, Mangano FG, Leone R, Sorrentino R. "Digitally oriented materials": focus on lithium disilicate ceramics. International journal of dentistry. 2016;2016.

32. Lien W, Roberts HW, Platt JA, Vandewalle KS, Hill TJ, Chu T-MG. Microstructural evolution and physical behavior of a lithium disilicate glass-ceramic. Dental materials. 2015;31(8):928-40.

33. Belli R, Geinzer E, Muschweck A, Petschelt A, Lohbauer U. Mechanical fatigue degradation of ceramics versus resin composites for dental restorations. Dental Materials. 2014;30(4):424-32.

34. Song X-F, Ren H-T, Yin L. Machinability of lithium disilicate glass ceramic in in vitro dental diamond bur adjusting process. Journal of the mechanical behavior of biomedical materials. 2016;53:78-92.

35. Bühler-Zemp P, Völkel T. IPS e. max CAD Scientific documentation. Ivoclar Vivadent. 2005:1-16.

36. Forster A, Ungvári K, Györgyey Á, Kukovecz Á, Turzó K, Nagy K. Human epithelial tissue culture study on restorative materials. Journal of dentistry. 2014;42(1):7-14.

37. Höland W, Apel E, van't Hoen C, Rheinberger V. Studies of crystal phase formations in high-strength lithium disilicate glass-ceramics. Journal of Non-Crystalline Solids. 2006;352(38-39):404150.

38. Denry I, Holloway J. Ceramics for dental applications: a review. Materials. 2010;3(1):351-68.

39. Fasbinder DJ, Dennison JB, Heys D, Neiva G. A Clinical Evaluation of Chairside Lithium Disilicate CAD/CAM Crowns. The Journal of the American Dental Association. 2010;141:10S-4S.

40. Gehrt M, Wolfart S, Rafai N, Reich S, Edelhoff D. Clinical results of lithium-disilicate crowns after up to 9 years of service. Clinical Oral Investigations. 2013;17(1):275-84.

41. Piconi $\mathrm{C}$, Maccauro G. Zirconia as a ceramic biomaterial. Biomaterials. 1999;20(1):1-25.

42. Christel P, Meunier A, Dorlot JM, Crolet JM, Witvoet J, Sedel L, et al. Biomechanical compatibility and design of ceramic implants for orthopedic surgery. Annals of the New York Academy of Sciences. 1988;523(1):234-56.

43. Miyazaki T, Nakamura T, Matsumura H, Ban $\mathrm{S}$, Kobayashi T. Current status of zirconia restoration. Journal of prosthodontic research.
2013;57(4):236-61.

44. Kelly JR, Denry I. Stabilized zirconia as a structural ceramic: an overview. Dental materials. 2008;24(3):289-98.

45. Denry I, Kelly JR. State of the art of zirconia for dental applications. Dental materials. 2008;24(3):299-307.

46. Manicone PF, lommetti PR, Raffaelli L. An overview of zirconia ceramics: basic properties and clinical applications. Journal of dentistry. 2007;35(11):819-26.

47. Kern M, Thompson VP. Bonding to glass infiltrated alumina ceramic: Adhesive methods and their durability. The Journal of Prosthetic Dentistry. 1995;73(3):240-9.

48. Kirmali O, Kustarci A, Kapdan A, Er K. Efficacy of surface roughness and bond strength of Y-TZP zirconia after various pre-treatments. Photomedicine and laser surgery. 2015;33(1):15-21.

49. De Mello CC, Bitencourt SB, dos Santos DM, Pesqueira AA, Pellizzer EP, Goiato MC. The Effect of Surface Treatment on Shear Bond Strength between Y-TZP and Veneer Ceramic: A Systematic Review and Meta-Analysis. Journal of Prosthodontics. 2018;27(7):624-35.

50. Garvie R, Hannink R, Pascoe R. Ceramic steel? Nature. 1975;258(5537):703.

51. Kim JE, Kim JH, Shim JS, Roh BD, Shin Y. Effect of Surface Treatment on Shear Bond Strength between Resin Cement and Ce-TZP/Al2O3. Biomed Res Int. 2016;2016:7576942.

52. Guazzato M, Albakry M, Ringer SP, Swain MV. Strength, fracture toughness and microstructure of a selection of all-ceramic materials. Part II. Zirconia-based dental ceramics. Dental Materials. 2004;20(5):449-56.

53. 53. Miranda RBP, Miranda WGJ, Lazar DRR, Ussui V, Marchi J, Cesar PF. Effect of titania content and biomimetic coating on the mechanical properties of the Y-TZP/TiO2 composite. Dent Mater. 2018;34(2):238-45.

54. Baldissara P, Llukacej A, Ciocca L, Valandro FL, Scotti R. Translucency of zirconia copings made with different CAD/CAM systems. The Journal of prosthetic dentistry. 2010;104(1):6-12.

55. Le M, Larsson C, Papia E. Bond strength between MDP-based cement and translucent zirconia. Dent Mater J. 2019;38(3):480-9.

56. Araujo AMM, Januario A, Moura DMD, Tribst JPM, Ozcan M, Souza ROA. Can the Application of Multi-Mode Adhesive be a Substitute to Silicatized/Silanized Y-TZP Ceramics? Braz Dent J. 2018;29(3):275-81.

57. Dal Piva AMO, Carvalho RLA, Lima AL, Bottino MA, Melo RM, Valandro LF. Silica coating fo- 
llowed by heat-treatment of MDP-primer for resin bond stability to yttria-stabilized zirconia polycrystals. J Biomed Mater Res B Appl Biomater. 2019;107(1):104-11.

58. Melo R, Souza R, Dursun E, Monteiro E, Valandro L, Bottino M. Surface treatments of zirconia to enhance bonding durability. Operative dentistry. 2015;40(6):636-43.

59. Yue X, Hou X, Gao J, Bao P, Shen J. Effects of MDP-based primers on shear bond strength between resin cement and zirconia. Exp Ther Med. 2019;17(5):3564-72.

60. Ahn JS, Yi YA, Lee Y, Seo DG. Shear Bond Strength of MDP-Containing Self-Adhesive Resin Cement and Y-TZP Ceramics: Effect of Phosphate Monomer-Containing Primers. Biomed Res Int. 2015;2015:389234

61. Yang L, Chen B, Xie H, Chen Y, Chen Y, Chen C. Durability of Resin Bonding to Zirconia Using Products Containing 10-Methacryloyloxydecyl Dihydrogen Phosphate. J Adhes Dent. 2018;20(4):279-87.

62. Treccani L, Klein TY, Meder F, Pardun K, Rezwan K. Functionalized ceramics for biomedical, biotechnological and environmental applications. Acta biomaterialia. 2013;9(7):7115-50.
63. He L-H, Swain M. A novel polymer infiltrated ceramic dental material. Dental Materials. 2011;27(6):527-34.

64. Coldea A, Swain MV, Thiel N. Mechanical properties of polymer-infiltrated-ceramic-network materials. Dental Materials. 2013;29(4):419-26.

65. Della Bona A, Corazza PH, Zhang Y. Characterization of a polymer-infiltrated ceramic-network material. Dental Materials. 2014;30(5):564-9.

66. Lawson NC, Bansal R, Burgess JO. Wear, strength, modulus and hardness of CAD/ CAM restorative materials. Dental Materials. 2016;32(11):e275-e83.

67. Eldafrawy M, Nguyen JF, Mainjot AK, Sadoun MJ. A Functionally Graded PICN Material for Biomimetic CAD-CAM Blocks. Journal of dental research. 2018;97(12):1324-30.

68. Nguyen J-F, Migonney V, Ruse ND, Sadoun M. Resin composite blocks via high-pressure high-temperature polymerization. Dental Materials. 2012;28(5):529-34.

69. Mainjot AK, Dupont NM, Oudkerk JC, Dewael TY, Sadoun MJ. From Artisanal to CAD-CAM Blocks: State of the Art of Indirect Composites. Journal of dental research. 2016;95(5):487-95.

RECONOCIMIENTO-NOCOMERCIAL-COMPARTIRIGUAL CC BY-NC-SA

ESTA LICENCIA PERMITE A OTROS ENTREMEZCLAR, AJUSTAR Y CONS-

TRUIR A PARTIR DE SU OBRA CON FINES NO COMERCIALES, SIEMPRE Y

CUANDO LE RECONOZCAN LA AUTORÍA Y SUS NUEVAS CREACIONES

ESTÉN BAJO UNA LICENCIA CON LOS MISMOS TÉRMINOS 